\title{
Understanding Complexity Leadership: Lesson From Emerging Environment
}

\author{
Agnieszka Dziubińska, PhD*
}

\begin{abstract}
In the article, the author concentrates on the exploration of the nature of leadership behaviours and their impact on organisational performance in multinational enterprises (MNEs) in turbulent environments. The results of studies were to answer the following two questions. How and which leadership approach helps understand adaptive processes in an emerging environment? What are complex leadership behaviours of MNEs and how do they influence a successful organisational performance? The article begins with theoretical foundations for the perception of leadership in the light of assumptions resulting from the complexity theory. Then, the empirical context for deliberations, i.e. behaviours of international enterprises in the conditions of emerging markets, is presented. Relationships between leadership and results obtained by organisations were described on the basis of the quality attitude of the case study. The research sample included five small and medium-sized MNEs developing their business activity on emerging markets (EMs). The results exhibit two strategies of dealing with the complexity of phenomena, i.e. complexity reduction and complexity absorption. The aim of the first one is convergence, the latter one is divergent in a distinct way. Effectiveness in both cases requires different activities to combine the administrative and the adaptive functions of leadership. Moreover, in surveyed companies, depending on which leadership types were dominated, the organisations were inclined to develop their activities in different domains of the environment of the emerging market. These tendencies may, in short-term, suggest a possible direction of development of organisations.
\end{abstract}

Keywords: leadership, complexity, emerging markets.

Submitted: 11.05.17 | Accepted: 29.01.18

\section{Przywództwo w warunkach złożoności - doświadczenia z działalności w warunkach rynków wyłaniających się}

Autorka koncentruje się na badaniu natury przywództwa i jego wplywu na działania organizacji $w$ warunkach turbulentnego otoczenia. W rozważaniach skupiono się na szczególnym przypadku organizacji, jakim jest przedsiębiorstwo międzynarodowe (MNE). Wyniki badań odpowiadają na następujące pytania: które z możliwych, oraz w jaki sposób, podejście do przywództwa odpowiada na procesy adaptacyjne w nowym otoczeniu rynków wytaniajacych się? Na czym polega przywództwo w warunkach ztożoności w MNE i jak wptywa ono na rezultaty organizacji? Artykut rozpoczyna przedstawienie podstaw teoretycznych w zakresie ujęcia przywództwa w świetle założeń wynikających z teorii złożoności. Następnie pokazano kontekst empiryczny rozważań, którym jest działalność MNE $w$ warunkach rynków wytaniających się. Część badawcza poświęcono określeniu związów między przywództwem a rezultatami

Agnieszka Dziubińska, PhD - University of Economics in Katowice, Faculty of Management.

Correspondence address: University of Economics in Katowice, Faculty of Management, Department of Enterprise Management, ul. 1 Maja 50, 40-227 Katowice; e-mail: agnieszka.dziubinska@ue.katowice.pl. 
uzyskiwanymi przez organizacje. W badaniach postużono się metoda jakościowa - studium przypadku. Próba badawcza objęto pięć matych i średnich przedsiębiorstw wielonarodowych prowadzacych działalność na rynkach wytaniajacych się. Wyniki wskazaty na dwie strategie radzenia sobie ze złożonościa zjawisk, które polegały na redukcji (konwergencji) lub absorbcji (dywergencji) złożoności. Skuteczność działania w obu przypadkach wymaga odmiennego taczenia administracyjnej i adaptacyjnej funkcji przywództwa. Ponadto badane firmy, w zależności od tego, które z typów przywództwa byly w nich dominujące, sktonne byly do rozwoju swojej działalności w oparciu o odmienne instytucje otoczenia rynków wytaniających się. Ujawnione tendencje moga, w krótkim okresie, sugerować kierunek rozwoju organizacji.

Słowa kluczowe: przywództwo, złożoność, rynki wyłaniające się.

Nadesłany: 11.05.17 | Zaakceptowany do druku: 29.01.18

JEL: M10, M16

\section{Introduction}

The conditionings of the contemporary environment entail specific managerial challenges, and enterprises are still on the lookout for efficient answers to them. One of such answers is a wave of development of transnational organisations with regard to the so called digital business (Coupey, 2004; Herdon, Varallyai, \& Pentek, 2012; Laudon \& Laudon, 2013; Mcquivey, 2013; Tapscott, 2015). In a knowledge-based economy (where the flow of knowledge is being deprived of traditional boundaries) (Grant, 2002; Corrallo, Passiante, \& Prenicipe, 2007; Schmidt \& Cohen, 2013), boundaries between companies and markets are becoming less apparent (Barrabba, Pourdehnad, \& Ackoff, 2002; Choo \& Bontis, 2002), boundaries in relationships between a designer and a consumer (e.g. in interactive media, set up products, etc.) (Strader, 2010) are disappearing. There is a growing tendency for disintermediation (Grant, 2000), as a result of which interconnections between informal institutions play a more significant role. Managers have a sense of extreme uncertainty while working in a non-ergodic world of continuous change (North, 2005; Cantwell, Dunning, \& Lundan, 2010). To remain competitive, together with a change of a competitive environment, companies have to change the mix in complexity ingredients (Casti, 1994; Brown \& Eisenharth, 1997; Andreson, 1999; Dooley \& Van de Ven, 1999; Maguire et al, 2006). Consequently, many traditional theories on management and organisation do not serve as a satisfactory basis for undertaken actions.

Leadership is one of the research areas where the outlined challenges play an essential role (Uhl-Bien, Marion, \& McKelvey, 2007; Hazy, 2006; Rokita, in print). On the one hand, it is becoming impossible to identify one, or at least a small number, of key factors leading to innovativeness, which is a condition for high outcomes - no single component is sufficient. On the other hand, a random mix of organisational components and behaviours is also ineffective. The application of assumptions of the complexity theory within this scope opens a very attractive ground for exploration. A vast part of literature which takes into consideration the complexity theory in the studies on leadership is based on experience of large organisations. It is justified by the fact that large organisations are more complex and at the same time offer a useful ground for exploration (Anderson, 1999; Zhichang, 2007; Kauffmann, 1993; Stacy, 2004; Tsoukas \& Hatch, 2001; Eisenhart \& Piezunka, 2011). However, the conditionings of the contemporary economic environment outlined above lead to a growing significance of a collaborative organisational form in which small and mid-sized enterprises constitute a basic element of increasing innovativeness and economic development (Grant, 2000). Thus, we may conclude that a more detailed exploration of the nature of leadership behaviours and their impact on organisational performance in MNEs in turbulent environments seems to be at least equally justified. In this paper, 
leadership is being considered from this very perspective. The results of studies that are presented in this paper were to answer the following two questions in particular: How and which leadership approach helps understand adaptive processes in an emerging environment? What are complex leadership behaviours of MNEs and how do they influence a successful organisational performance?

The choice of EMs as an empirical context for the studies was justified by the specific feature of these markets, i.e. institutional voids. Institutional limitations are one of the criteria which classify markets as emerging ones. An EM is a market where advanced institutions supporting transactions between the buyer and the seller on the market, labour or capital market do not exist or they function in an inefficient manner. According to this structural definition, emerging markets are placed on the continuum between totally dysfunctional markets and developed markets (Khanna and Palepu, 2010, p. 24-25). In this respect, institutions should be regarded as "rules of the game", i.e. as "socially created limitations which give a structure to social interactions" (North, 1990, p. 3). The role of an institution is "reduction of uncertainty by establishing stable (though not necessarily effective) structures in human interactions (...) institutions affect the results of the whole economy by means of their influence on the costs of exchange and production" (North, 1990, pp. 5-6).

From the perspective of the research subject, EMs create an interesting "research laboratory" since one of the features of complex systems is the fact that the system itself as well as its components, or agents, constrain one another (in organised systems, the system constrains agents, whereas in chaotic systems there are no constraints). Therefore, on the one hand, on the basis of the theory of institutional economics, the lack of intermediary institutions is considered a "disability", and it is interpreted as a limitation for the transparency of processes which take place in the environment. ${ }^{1}$ Poorly secured transactions, communication and transparency may create opportunities for opportunistic behaviours of partners, and it increases uncertainty (Khanna and Palepu, 1997). On the other hand, in view of assumptions of complexity, not only can it not be reduced due to its nature, but it should be absorbed since in this way innovations which guarantee the existence of the system emerge.

The next section presents theoretical foundations for the perception of leadership in the light of assumptions resulting from the complexity theory. Then, the empirical context for deliberations, i.e. behaviours of MNEs in the conditions of an emerging environment, is presented. Relationships between leadership and results obtained by organisations were described on the basis of the quality attitude of the case study. The research sample included five MNEs developing their business activity on EMs. The summarising part refers to the research questions posed in the introduction.

\section{Theoretical Framework: Complexity and Leadership}

In the field of organisation theory, the first inspirations for the conceptualisation of ways to adapt complex systems originated from the theory of chaos and dissipative structures. On their basis, complex systems were defined as iterative, selforganising organisations which emerge on the way of a large number of interactions between the elements of an organisation taking place within the organisation, out of the organisation and on the border of the organisation and its environment (Thietart and Forgues, 1995). A significant feature of complex adaptive systems (CAS) is, therefore, the fact that the adaptation takes place with the aid of interaction and not on the basis of the analysis (Reynolds, 1987; Ray, 1992; Gell-Mann, 1994; Holland, 1998; Kauffman, 1995; Langton, 1996). In organisational and management sciences, studies on complex systems were to a larger extent conducted on the basis of computer simulations within the industry where agents undertook their actions guided by simple rules (Levy, 1994; Marion, 1999; Allen et al., 1998a; Allen et al., 1998b; Allen, Strathern and Baldwin, 2006). Beside the simple rule trend, another trend emerged over time in which the authors argued that social systems are not shaped in the same way as inanimate systems due to human intelligence and unpredictability (Stacey, 2011; Juarrero, 1999, Snowden and Stanbrigde, 2004). From this perspective, complexity is a way of thinking which helps 
leaders make sense of advanced technologies, globalisation, entangled markets and cultural changes.

Complex systems are characterised by features which encourage a revision of at least some of the fundamental assumptions acknowledged in management (Rokita and Dziubińska, 2016). From this viewpoint, a few of the most important general features of complex systems should be distinguished. First and foremost, the nature of complex systems is emergent, i.e. their dynamics results in the fact that the whole equals something more than just a sum of its elements, and that the elements can be something more and something less than the parts. The most significant results of emerging in complex systems appear not only at the level of the whole (e.g. enterprise) but also at the level of individual elements (e.g. people). In such conditions, solutions cannot be imposed in advance, but they should rather emerge from the circumstances. These circumstances create interactions of a great number of elements; however, they may not be linear: Small changes may have disproportionately huge consequences. The elements of the system evolve between one another and together with the environment. The evolution is irreversible, and each system has its own history which is connected with contemporaneity. Although past events in complex systems may seem organised and predictable, they may not repeat in the future since the environment as well as the system itself undergo a continuous change. Thereby, past patterns do not constitute the basis for prediction.

The results of studies on complex systems lead to the conviction that leaders who want to use the potential of complexity to innovate within their organisations should rather act differently than it follows from the traditional approach. Detailed criticising arguments of a top-down management and control of an organisation were presented by McKelvey (2001). Marion and Uhl-Bien (2003) visibly distinguish leadership exercised in the conditions of complexity from transformational leadership which is exercised by individual CEOs gifted with vision and charisma. The aspects related to leadership that favours innovations and takes into consideration the complex nature of systems were the subject of studies within the scope of connective leader- ship (Lipman-Blumen, 1996), catalytic leadership (Luke, 1998), collaborative leadership (Chieslip, 2002), emergent leadership (Curtin, 2004) and integrative leadership (Crosby and Bryson, 2010). However, the fact that individual leaders who used a diversified range of methods and tools supporting the interaction between mutually dependent agents were the subject of the study should be regarded as a limitation to these concepts. If we assume that the adaptation to the environment takes place on the basis of complex interactions between agents, leadership should be regarded as a complex dynamic process which is not present in a single individual (Lichtenstein et al., 2006), but rather different individuals could emerge as leaders at different moments as their identity is being formed during interactions.

In complex systems, leadership cannot be considered to be an individual role but a phenomenon which is shaped by dynamic interactions (Lichtenstein et al., 2006; Hazy, 2006; Osborn, Hunt and Jauch, 2006; Nooteboom and Termeer, 2013). The challenge within the scope of leadership is as follows: "How can organisations enable and coordinate CAS dynamics and informal emergence (where appropriate) without suppressing their adaptive and creative capacity?" (Uhl-Bien, Ross and McKelvey, 2007 , p. 304). For the purposes of describing the dynamics of a business organisation as CAS, two types of interactions which create it should be distinguished. On the one hand, the organisation has its own legitimate system which consists of links that are formally and intentionally established by most powerful members of the organisation. If the conditionings of the environment at a particular moment favour rational structures and coordination (e.g. in case of stable environment where the system is focused on the improvement of results), the application of formal top-down administrative forces is justified. The objectives of such interactions are clear and relatively easily understood, and the boundaries are clear-cut. On the other hand, within each organisation, there are informal relationships between its members; they are in the shadow of the first ones (Stacey, 1996). The latter system is of a spontaneous nature; therefore, it is quite clearly nonlinear. It also creates conditions for organisational innovation since there are many different possible responses 
to a given stimulus, which may be more or less proportional. The system is identified with the abilities of the organisation to adapt in complex conditions (e.g. when environments are volatile or the flexibility of the competition is threatening). There is a constant game between these systems, which may serve as a ground for action for leaders. From that perspective, in large organisations, tools for the institutionalisation of innovation were connected, among other things, to a continuous manipulation of the design of the organisation so that various subunits, teams, departments could be brought together in performing various tasks, projects, long-term programs (Surie and Hazy, 2006; Eisenhardt and Brown, 1999).

The framework for leadership that enables the learning, creative and adaptive capacity of CAS in a knowledge-producing organisation is Complexity Leadership Theory (CLT) (Uhl-Bien, Ross and McKelvey, 2007; Uhl-Bien and Marion, 2009). This framework "seeks to foster CAS dynamics at the same time enabling control structures appropriate for coordinating formal organizations and producing outcomes appropriate to the vision and mission of the system. It seeks to integrate complexity dynamics and bureaucracy, enabling and coordinating, exploration and exploitation, CAS, and hierarchy, and informal emergence and top-down control" (Uhl-Bien, Ross and McKelvey, 2007, p. 304). CLT envisions three leadership types: administrative, adaptive and enabling.

Administrative leadership constrains spontaneous innovation. It refers to the actions of persons within the framework of formal managerial roles who have formal authority, implemented by hierarchical structures. Administrative leadership is deeply rooted in "traditional bureaucratic notations of hierarchy, alignment and control" (Uhl-Bien, Ross and McKelvey, 2007, p. 299). Actions undertaken by administrative leaders consist, among other things, in setting goals, planning, creating vision, disposing of resources necessary for the achievement of goals, dealing with critical situations, managing strategy of the organisation. Administrative leadership corresponds with the concept of leadership in traditional corporations. Leaders interact within formal networks, get together in formal meetings. Assessment and moti- vation systems are related to measurable results set on the basis of formal regulations. Administrative leadership does not favour innovation.

Adaptive leadership is responsible for new ideas, innovation and change. This type of leadership is rooted in interactions of agents with regard to contrasting needs and ideas. As a result, adaptive leadership favours development of a collaboration network, making temporary alliances and, as a consequence, action of an organisation. This form of leadership occurs in informal networks - in the shadow of the organisation. Adaptive leaders may gain support if they are able to convince administrative leaders that it does not influence the interests of administrative leaders and, at the same time, contributes to the improvement of results of the system as a whole.

Joining administrative and adaptive types of leadership in an effective way, i.e. managing entanglement, becomes a challenge that the organisation has to face (Uhl-Bien, Ross and McKelvey, 2007). In CLT, this entanglement is implemented by means of enabling leadership. Its purpose is to create conditions that favour the emergence of innovation. Enabling leadership "works to catalyse the conditions in which adaptive leadership can thrive and to manage the entanglement between the bureaucratic (administrative leadership) and emergent (adaptive leadership) functions of the organization" (Uhl-Bien, Ross and McKelvey, 2007, p. 305). Therefore, enabling leadership refers to leaders who are able to connect the need for particular innovation with the position within a legitimate network. Enabling leaders are capable of changing alliances within formal networks and facilitate the flow of knowledge, which favours innovation.

Depending on the relationship between administrative and adaptive roles, enabling leadership may assume a different form. If administrative and adaptive leaderships are well integrated, the enabling one is not apparent. If administrative leadership is stifling adaptive leadership, the enabling one is needed to protect and foster adaptive leadership and integrate it into the administrative one. Consequently, in circumstances in which adaptive leadership is healthy but not integrating into the administrative one, enabling leadership needs to integrate adaptive leadership into adminis- 
trative leadership. And finally, if administrative and adaptive leaderships both occur but are not connected, enabling leadership is needed to create the connection.

The transparency of CLT is its undoubted advantage although it results from a high level of generality. However, what should be emphasised is that the assumptions of CLT are rooted in the field of research, mentioned above as "simple rules". According to this approach, rules of behaviour are applied consistently, and are either engendered by behaviour issues such as self-interest, or determined by high authority. The entrepreneurial approach may need a degree of ambiguity of interpretation. The assessment of usefulness of CLT requires its application in a particular empirical context. The EM environment was chosen for further deliberations. Institutions of EMs may provide a general guidance in which the extremes of tolerable and intolerable behaviours are clear, but for which there is a large grey area where interpretation is key.

\section{Behaviours of MNEs in the Conditions of Emerging Markets}

Complexity gives systems features which happen to be described as "the life of the system" (Capra, 2002). Living organisations are dependent on their environment not only within the scope of matter and energy but also knowledge and information. In contemporary economy, enterprises may avail themselves of unprecedented possibilities for development on a worldwide scale; however, paradoxically, greater autonomy in activities makes them more dependent on technology, collaboration network, social and material constraints (E. Morin defines this relationship as a relationship of "logical complexity autonomy-dependency"). It may be anticipated that due to its relationship with the environment the system may undergo transformation in two ways, i.e. either through the growth of complexity or complexity reduction. According to the hierarchy theory (Odum and Odum, 2006), a living system may evolve through horizontal development of its structural complication within the framework of a flat structure or through vertical development of its organisational complexity within a deep hierarchy (Allen, Tainter and Hoekstra, 1999). Using this terminology, a flat hierarchy is a complicated system of system resources which bring little profit. A deep hierarchy as an integrated complex system uses the resources which bring greater profits and reaches greater overall efficiency (Allen et al., 2009; Allen et al., 2010). Although traditionally greater efficiency is regarded as an advantage, the risk of failure of such a system is higher than in case of a loosely connected structure. This view corresponds to two strategies of dealing with the complexity of phenomena, i.e. complexity reduction and complexity absorption (Boisot and Child, 1999). The aim of the first one is convergence, the latter one is divergent in a distinct way (Tsoukas and Hatch, 2001, p. 981). In this context, we may also talk about two different types of organisation of international enterprises, i.e. these which are closer to the traditional approach towards business activity (Dziubińska, 2015) and these which made contemporary conditionings the basis of their advantage (Dziubińska, 2017a). A traditional international enterprise may be characterised (among others) as managed to achieve goals based on ideal models and central planning, oriented on efficiency (based on core capabilities), and exploitation. In contrast, in case of the second type, managers focus on starting conditions and monitor for the emergence of patterns which will be sustained or disrupted; the main logic of development is effectiveness (based on requisite diversity) and exploration.

The environment of the organisation may be perceived as a set of specific institutions shaping business activity of the organisation. Mechanisms which exist here facilitate or hinder the development of existing types of organisations and the appearance of new ones. According to North, the institutional framework consists of formal and informal constraints around individual and organisational behaviours. Formal constraints include political (and legal) rules, economic rules and contracts. Informal constraints include codes of conduct, norms of behaviour, and convention, which are embedded in culture and ideology (North, 1990, pp. 36, 46). Enterprises do not need to be doomed to passive adjustment, but they may change their institutional environment through the development of strategic initiatives. In response to the institutional framework, organisations decide 
for a number of strategic solutions which are the manifestation of their acquiescence, active affiliation or reluctance (Oliver, 1991). With reference to MNEs, Cantwell, Dunning and Lundan (2010) described three ways of MNE's institutional engagement: institutional avoidance, institutional adaptation and institutional co-evolution.

These theses give a wide scope for searching for ways of neutralising institutional voids. The ability to develop such initiatives happened to be identified with entrepreneurship and institutional entrepreneurs (DiMaggio, 1988). Institutional entrepreneurs are individuals who can unofficially lead interaction networks and in this very way antinomically organise support for innovation (Hargrave and Van De Ven, 2006; Raffaelli and Glynn, 2015). Policy entrepreneurs were also similarly depicted in the literature (Kingdon, 1984), and so were reformist leaders (Goldfinch and Hart, 2003). By means of applying the assumptions of CLT concerning the contribution of three key leadership types to innovation (Uhl-Bien, Ross and McKelvey, 2007; Uhl-Bien and Marion, 2009) and forms of MNE's institutional engagement, it is possible to develop a typology of three possible points of view on EM institutions.

Tab. 1. Operationalisation of types of leadership in the context of the attitude towards specific conditionings of EM institutions. Source: Own study with the use of Cantwell, Dunning and Lundan (2010, p. 576)

\begin{tabular}{|c|c|}
\hline $\begin{array}{l}\text { Leadership } \\
\text { function }\end{array}$ & Attitude towards institutions of foreign market environment \\
\hline Administrative & $\begin{array}{l}\text { - institutional environment is exogenic for the company; } \\
\text { - the company may choose between various environments; } \\
\text { - companies react to poor quality of institutions by adjusting their entry } \\
\text { model. }\end{array}$ \\
\hline Adaptive & $\begin{array}{l}\text { - institutional environment is exogenic for the company, } \\
\text { but the company adapts its behaviours to achieve greater adjustment; } \\
\text { - companies may attempt to influence local institutions, but to a limited } \\
\text { extent; } \\
\text { - companies gain strategic options as a result of learning and company } \\
\text { adaptation; } \\
\text { - embeddedness in the institutional context. }\end{array}$ \\
\hline Enabling & $\begin{array}{l}\text { - institutional environment is partially exogenic for the company; } \\
\text { - companies adjust themselves to various institutional environments through } \\
\text { the process of coevolution; } \\
\text { - companies introduce new institutions which are adapted to the local context; } \\
\text { - unintended spill-over effect occurs as a result of local imitation; } \\
\text { - the enterprise as an active agent (institutional entrepreneurship). }\end{array}$ \\
\hline
\end{tabular}

The studies on enterprises investing on EMs create a perfect opportunity for a deeper comprehension of interactions between organisations and the environment. Traditional literature on international business was written on the basis of experiences from the so called developed markets. However, the environments of western markets were shaped by a relatively similar philosophy of market economy which gave the basis for similar rules of competitive game, whereas the possibility to recognise the influence of institutions on social structures and behaviours is dif- ficult or even impossible if all our cases are embedded in the same or very similar conditions (Scott, 2001, p. 146).

Institutions differ in the extent to which they are formalised and evident, also in the possibilities of being recognised by external entities, such as MNEs. On the basis of the theory, it may be expected that in the conditions in which formal constraints fail, informal constraints begin to play their role (North, 1990; Powell, 1990; Scott, 2001; Peng and Heath, 1996; Peng, 2003). The thesis corresponds to the traditional theory of MNE. The so called pillars of the envi- 
ronment refer to this issue more deeply (Scott, 2001). A regulative pillar stands for institutions such as rules and legal regulations which exist to ensure order and stability within the society (North, 1990; Williamson, 1975; Williamson, 1991). Enterprises are obliged to operate in accordance with formal regulations; however, it does not rule out the fact that in a longer period of time they become deprived of influence on these rules. A normative pillar (exceeding formal norms or knowledge) is connected with legitimisation. Binding social norms, values and convictions set borders for actions regarded as desirable and proper (Zimmerman and Zeitz, 2002). It is a "level of cultural support for the organisation" determined by the correspondence of values represented by the organisation and the environment (Meyer and Scott, 1983 p. 201). A cognitive pillar refers to cognitive social structures, convictions taken for granted, which are accepted and used by social actors (Di Maggio and Powell, 1983). This domain is connected with the field appendant to social psychology (Berger and Luckmann, 1967; Kostova and Zaheer, 1999) and a cognitive trend of the institutional theory (Meyer and Rowan, 1977).

These pillars do not have to be treated separately; it can be quite the opposite. In a long period of stabilisation, a state of complimentary correspondence between them is more probable (Scott, 2001). For example, values influence cognitive categorisation and in a long-term perspective, regulations. The latter ones, in turn, influence the values. Socio-economic processes, however, create a situation in which the environment of emerging markets is shaped by non-continuous changes (Peng, 2003). The result is not only a non-linear, sudden nature of the changes, but also a possible lack of correspondence between the pillars. It is a specific type of institutional voids existing on emerging markets.

On the basis of behaviours of the enterprises regarding these institutional voids, the types of operating leaderships may be concluded. The dominant activity of particular types of leadership may suggest probable directions of development of the enterprises. It should be emphasised that only a short-term perspective may be considered here since, when developing new spheres of value creation or pioneering new institutions, humans exercise choice, judgement and creativity. That way, in contexts that are fundamentally uncertain, they may initiate a transformation of the system of which they are part, as well as they may transform themselves. Moreover, the perspective of complexity leadership brings innovation and self-organisation to the lower level of the hierarchy, making the entity more responsive to the environment as mutual understanding among employees is amplified during interaction (Kaufmann, 1993; Stacey, 2011; Karakas, 2009; Hazy, 2006; Scott, 2004).

\section{Methodology}

The qualitative approach with the use of a case study was applied in the research. The results of the study which are presented in the next section were obtained on the basis of an analysis of existing data gathered for the purposes of another study within the scope of the strategy of international enterprises on emerging markets (conducted between February 2009 and December 2012). The description of methodology used in the primary study and a detailed description of cases were presented by the author in the article "Institutional innovation in the conditions of environment transformation" (Dziubińska, 2017a). ${ }^{2}$

The use of existing data was justified since the application of the leadership perspective in the conditions of complexity in relation to previously obtained research results made it possible to widen and deepen the interpretation. To be more precise, the previous study aimed at determining if and in what way - in the conditions of experience complexity of the environment - its institutions may be constraining and/or facilitating for enterprises in running their business activity. The area of the analysis was, therefore, focused on the "agentsystem" relations. Taking into consideration another dimension, i.e. the types of leadership, makes it possible to complete the interpretation with the conclusions regarding a dynamic combination of initiatives undertaken by the agents. The current study aimed at searching for possible patterns and their prospective relationships with the results obtained by the enterprises included in the study. The research procedure within the framework of which the primary data were gathered was designed 
on the basis of the methodology suggested by Dul and Hak (2008). The aim of the study, which was to discover factors in the investigated cases that influence the configuration of actions in the conditions of complex environment, justified the use of an exploratory case study and a nonprobability sampling for the research sample. Table 2 presents the characteristics of cases in the research sample. While determining the size of the sample, constraints connected with the necessity to process a large amount of data were taken into considera- tion among other things. The sampling was also to ensure the best possible access to data. There were five entities included in the sample. These were headquarters and foreign branches of small and midsized international enterprises operating within one industry: producers of mining machines and their parts. The sampling of companies representing one industry was a deliberate choice which facilitated the comparison of the cases. Various industries are to a different extent dependent on market institutions.

Tab. 2. Basic characteristics of companies in the research sample

\begin{tabular}{|l|l|c|c|c|l|}
\hline $\begin{array}{c}\text { Case } \\
\text { (company) }\end{array}$ & $\begin{array}{c}\text { Country } \\
\text { of origin }\end{array}$ & $\begin{array}{c}\text { Amount } \\
\text { of turnover } \\
\text { (FDI / company; } \\
\text { in EUR mIn) }\end{array}$ & $\begin{array}{c}\text { Number } \\
\text { of employees } \\
\text { (FDI / whole } \\
\text { company) }\end{array}$ & $\begin{array}{c}\text { Location } \\
\text { of selected FDI } \\
\text { (entry time) }\end{array}$ & $\begin{array}{c}\text { Organisational } \\
\text { form of FDI }\end{array}$ \\
\hline Company I & Poland & $3 / 7$ & $50 / 90$ & $\begin{array}{l}\text { Colombia } \\
(2007 / 2012)\end{array}$ & Own branch/JV \\
\hline Company II & Germany & $23 / 45$ & $50 / 300$ & $\begin{array}{l}\text { China } \\
(2003 / 2008)\end{array}$ & JV/Own branch \\
\hline Company III & Italy & $128 / 323$ & $600 / 2800$ & Malaysia (1988) & Own branch \\
\hline Company IV & Poland & $4 / 70$ & $23 / 120$ & $\begin{array}{l}\text { Russia } \\
(2007-2009)\end{array}$ & JV \\
\hline Company V & Germany & $11 / 63$ & $25 / 160$ & China (2008) & JV \\
\hline
\end{tabular}

The data were obtained from a few sources to ensure accuracy and reliability of research results. Within the scope of the field research, empirical material was gathered with the use of a structured direct interview and an unstructured direct interview. The interviews were conducted among the companies' CEOs, CEOs of the branches and employees who possess knowledge that was significant from the perspective of the research objectives. In the course of the whole research procedure, a constant contact with the representatives of the investigated companies was ensured. The information obtained in this way was also a valuable source which helped to understand better the phenomena taking place within the organisations. The research assumptions were supposed to ensure a detailed insight into the processes which took place throughout the history together with their context.

Tab. 3. Overall results from the cases investigated

\begin{tabular}{|c|l|l|l|}
\hline & $\begin{array}{c}\text { Manifestations } \\
\text { of administrative leadership }\end{array}$ & \multicolumn{1}{c|}{$\begin{array}{c}\text { Manifestations } \\
\text { of adaptive leadership }\end{array}$} & $\begin{array}{c}\text { Manifestations } \\
\text { of enabling leadership }\end{array}$ \\
\hline \multirow{3}{*}{$\begin{array}{l}\text { - Low standard of the } \\
\text { mining law as a ground } \\
\text { for collaboration with } \\
\text { business partners, } \\
\text { trade organisations and } \\
\text { representatives of state } \\
\text { administration; }\end{array}$} & $\begin{array}{l}\text { - Mutuality of interest as } \\
\text { a security for performance } \\
\text { of contracts; }\end{array}$ & $\begin{array}{l}\text { - Winning trust } \\
\text { of prospective clients } \\
\text { through open presentation } \\
\text { of implemented projects; }\end{array}$ & $\begin{array}{l}\text { Lack of qualified } \\
\text { workforce was the reason } \\
\text { for the establishment of } \\
\text { original work teams; } \\
\text { - Participation as an } \\
\text { expert in a governmental } \\
\text { educational programme; }\end{array}$ \\
\hline
\end{tabular}


continued Tab. 3

\begin{tabular}{|c|c|c|c|}
\hline & $\begin{array}{c}\text { Manifestations } \\
\text { of administrative leadership }\end{array}$ & $\begin{array}{c}\text { Manifestations } \\
\text { of adaptive leadership }\end{array}$ & $\begin{array}{c}\text { Manifestations } \\
\text { of enabling leadership }\end{array}$ \\
\hline & $\begin{array}{l}\text { - Participation in } \\
\text { consultations concerning } \\
\text { creation of the mining } \\
\text { law; } \\
\text { - Running current business } \\
\text { activity to the largest } \\
\text { possible extent within the } \\
\text { company }\end{array}$ & $\begin{array}{l}\text { - Demonstration of the } \\
\text { intention for long-term } \\
\text { engagement on the } \\
\text { market; } \\
\text { - Raising social standards } \\
\text { for employees from the } \\
\text { local market. }\end{array}$ & $\begin{array}{l}\text { - } \text { Open sharing of } \\
\text { knowledge with a wide } \\
\text { group of stakeholders; } \\
\text { - } \text { Reinforcement of applied } \\
\text { technical standards (also } \\
\text { by linguistic measures); } \\
\text { - Employees' trainings; } \\
\text { learning a foreign } \\
\text { language was equally } \\
\text { important as technical } \\
\text { knowledge; } \\
\text { - In case of unforeseen } \\
\text { technical difficulties, } \\
\text { solutions from home } \\
\text { and local markets were } \\
\text { combined; } \\
\text { - Attempts to fill positions } \\
\text { on higher managerial } \\
\text { levels with local managers. }\end{array}$ \\
\hline 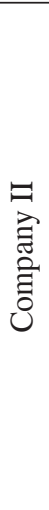 & $\begin{array}{l}\text { - Application of legal } \\
\text { protection of patents } \\
\text { supported by hidden } \\
\text { technical solutions; } \\
\text { - } \text { Mining law regulations } \\
\text { as an element that } \\
\text { encourages the company } \\
\text { to adapt its products; } \\
\text { - Running current } \\
\text { operational activity in the } \\
\text { form of outsourcing. }\end{array}$ & $\begin{array}{l}\text { - Creating an image of an } \\
\text { innovative, high standard } \\
\text { company; } \\
\text { - } \text { Introduction of local } \\
\text { elements into the image of } \\
\text { the company; } \\
\text { - } \text { Building strong } \\
\text { relationships with clients; } \\
\text { - Limited placement of the } \\
\text { most important elements } \\
\text { of the activity on the } \\
\text { foreign market out of fear } \\
\text { of being copied. }\end{array}$ & $\begin{array}{l}\text { - } \text { "Controlled" } \\
\text { collaboration with } \\
\text { state R+D units and } \\
\text { collaboration with } \\
\text { universities of technology; } \\
\text { - } \text { Internships for students } \\
\text { which increase chances } \\
\text { for winning employees } \\
\text { with appropriate technical } \\
\text { qualifications; } \\
\text { - Adaptation of own } \\
\text { technical solutions to } \\
\text { local (trade and technical) } \\
\text { requirements. }\end{array}$ \\
\hline 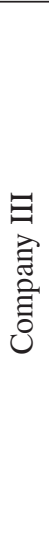 & 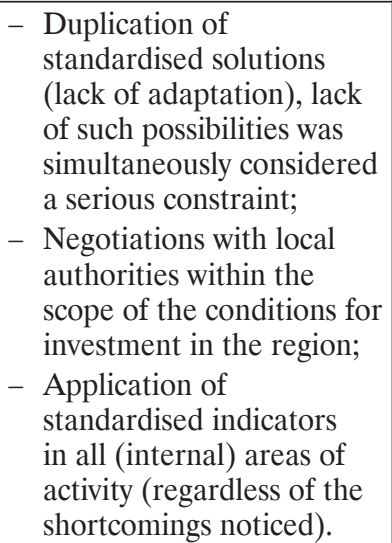 & $\begin{array}{l}\text { - Preservation of quality as } \\
\text { an absolute value; } \\
\text { — Local organisation culture } \\
\text { identified as one of the } \\
\text { main barriers to the } \\
\text { activity; } \\
\text { - The study revealed only } \\
\text { one case of adaptation } \\
\text { by own initiative, i.e. the } \\
\text { department CEO's "trick" } \\
\text { implemented thanks to } \\
\text { a great knowledge of } \\
\text { procedures and personal } \\
\text { relationship with board } \\
\text { members. }\end{array}$ & $\begin{array}{l}\text { - One of the ways of } \\
\text { levelling local constraints } \\
\text { was to invite existing } \\
\text { collaborators to co-invest } \\
\text { abroad; } \\
\text { - Building a JV network } \\
\text { according to a settled } \\
\text { ex ante sequence and } \\
\text { standardised criteria. }\end{array}$ \\
\hline
\end{tabular}




\begin{tabular}{|c|c|c|c|}
\hline & $\begin{array}{c}\text { Manifestations } \\
\text { of administrative leadership }\end{array}$ & $\begin{array}{c}\text { Manifestations } \\
\text { of adaptive leadership }\end{array}$ & $\begin{array}{c}\text { Manifestations } \\
\text { of enabling leadership }\end{array}$ \\
\hline & $\begin{array}{l}\text { - Careful attention paid } \\
\text { to running the activity } \\
\text { in accordance with the } \\
\text { regulations (reluctance to } \\
\text { "evade" the law); } \\
\text { - Formal management } \\
\text { system whose rules were } \\
\text { reprieved by the decisions } \\
\text { of the company's CEO. }\end{array}$ & $\begin{array}{l}\text { - Declared willingness to } \\
\text { collaborate with local } \\
\text { clients as the basis of } \\
\text { learning about their } \\
\text { needs; } \\
\text { - Service teams recruited } \\
\text { among local employees } \\
\text { (by the local JV partner); } \\
\text { - "Low culture of work" } \\
\text { identified as one of the } \\
\text { reasons for the lack of } \\
\text { efficiency. }\end{array}$ & $\begin{array}{l}\text { - Clear (and rigid) division } \\
\text { of tasks between the } \\
\text { headquarters and the local } \\
\text { partner; } \\
\text { - High level of engagement } \\
\text { of the company's CEO } \\
\text { who made all important } \\
\text { decisions by himself; } \\
\text { - Directions of development } \\
\text { set by the CEO } \\
\text { - "a visionary"; } \\
\text { - Lack of agreement } \\
\text { with the local partner } \\
\text { concerning strategic } \\
\text { goals as the main reason } \\
\text { for withdrawal from the } \\
\text { market. }\end{array}$ \\
\hline 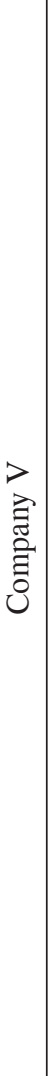 & $\begin{array}{l}\text { - Formal rules of market } \\
\text { research and standardised } \\
\text { rules related to contacts } \\
\text { with clients; } \\
\text { - Formal rules of } \\
\text { assessment in each aspect } \\
\text { of business activity, } \\
\text { especially within the scope } \\
\text { of collaboration with a } \\
\text { foreign representative; } \\
\text { - Formal rules of project } \\
\text { management (procedures, } \\
\text { IT tools, documentation, } \\
\text { meetings); } \\
\text { - Application of formal } \\
\text { agreements with all the } \\
\text { partners; } \\
\text { - Application of the } \\
\text { patent law as a form of } \\
\text { protection. }\end{array}$ & \begin{tabular}{|l|}
- Important decisions \\
related to the local market \\
consulted with other \\
experienced companies \\
from the home market; \\
- All rules established at the \\
headquarters; \\
- Low level of resource \\
engagement on the local \\
market due to high risk; \\
- Adaptation understood \\
only through adjustment \\
of the product; however, \\
there is also a declaration \\
about the lack of need \\
to change due to the \\
technical standard \\
which is higher in \\
comparison with the \\
local one (only one, \\
very little modification \\
of the product under \\
the influence of local \\
demands was identified); \\
- Scope of adaptation \\
recommended by the JV \\
partner was assessed as \\
too large;, consequently, \\
the company withdrew \\
from the market.
\end{tabular} & $\begin{array}{l}\text { - Sales present only on } \\
\text { the local market, other } \\
\text { tasks accumulated at the } \\
\text { headquarters for their } \\
\text { protection; } \\
\text { - Technical teams set up } \\
\text { at the headquarters } \\
\text { for the purposes of } \\
\text { implementation of } \\
\text { important projects (each } \\
\text { time on the basis of } \\
\text { the company's CEO's } \\
\text { decision); } \\
\text { - Relatively free } \\
\text { communication within the } \\
\text { company, restrictive rules } \\
\text { of sharing information } \\
\text { outside the company; } \\
\text { - Goals set "from above", } \\
\text { but employees may } \\
\text { comment on them; } \\
\text { - Information about foreign } \\
\text { markets gathered by the } \\
\text { headquarters (also during } \\
\text { annual meeting of the } \\
\text { company's representatives } \\
\text { from all over the world). }\end{array}$ \\
\hline
\end{tabular}

In the current study, raw data underwent encoding. The data were assigned to leadership types: administrative, adaptive and enabling (Table 3). The analysis was made by comparing the cases in pairs in different cross-sections, i.e. according to the country of origin and country of investment, size and form of FDI and strategic 
results (success - failure). The same crosssections were used in the primary study. These actions influence the possibilities of drawing conclusions and connecting them with the results which were previously obtained.

\section{Findings and Analysis}

The perspective of complexity made it possible to consider the issue of leadership, adaptation of the organisation to the new context of institutional environment in one conceptual framework. Such conceptualisation, in particular, made it possible to take a closer look at the relations between the agent and the system and to notice possible patterns within this scope. Table 4 contains a synthetic summary of the obtained results. Below are the results which are most significant from the point of view of the subject of this paper and which were obtained by way of comparing the cases according to strategic effectiveness (operationalised as a level of achieving strategic goals, and the results above the expectations were also taken into account) and replication or innovation of experiences in the conditions of the local market (replication is understood here as a transfer of core products and/or the whole business models which were developed on other markets; innovation stands for development of key products and/or the whole business models on the basis of experiences from the investment market)

In case of MNEs investing on EMs, the common elements were actions developed on the basis of administrative leadership, which was applied in a broader scope of activity in a regulative domain of the environment. The observation is not surprising since each enterprise has its own legitimated system and is subject (partially forcibly) to the provisions of the law. It may be stated that each enterprise has its own orderly image. The differences observed between the investigated cases may seem to be more interesting.

The most general conclusion that may be drawn from the analysis concerns two different ways of handling complexity. It becomes visible if we compare the cases of Companies III, II and V (i.e. the ones which carried out replication). Company III implemented practically the whole adaptation on the basis of admin- istrative leadership. The objectives and modus operandi were clear to all employees. The number of actions which corresponded to the characteristics of enabling leadership was not high, and they altogether aimed at levelling prospective influence of foreign market institutions, which could result in a change in the organisation. The way of configuration and development of the activity on the level of the whole enterprise and FDI corresponded to the image which is reinforced in classic literature on international business. It should be emphasised that it was the case of the largest company in the research sample. Company III reached its strategic goals to a satisfying extent (it belonged to the group of the largest companies on the international market within the scope of the activity selected for the study) by applying a convergent strategy of handling the complexity of the EM environment. A similar approach did not prove to be successful in case of Company $\mathrm{V}$ (which withdrew from the market). Company II was regarded as efficient; however, in this case (contrary to Company V) active actions in all three leadership types were identified. Companies V and II are much smaller than Company III. The observation may be summarised in the following way: The dominant role of administrative leadership leads to the reduction of complexity by the organisation. Effective application of this strategy (convergence) requires appropriate market power. Reduction of complexity without appropriate market power (Hymer, 1976) (which, in the investigated case, was delivered by the accumulation of capital) leads to strategic inefficiency. The cases of Companies I and IV do not contradict these conclusions.

What was common for Companies II, V, I, IV (and, at the same time, different in relation to Company III) was the fact that they did not have at their disposal traditional attributes of competitive advantage on the foreign market. It may suggest that the lack of market power requires absorption of complexity (divergence). In this group of cases, Companies II and I proved to be effective: In both cases the actions appropriate for all three leadership types were undertaken. The cases in the research sample confirm, therefore, the CLT thesis which states that complex systems actively combine all three leadership types. 
Tab. 4. Strategic efficiency and leadership types

\begin{tabular}{|c|c|c|c|c|}
\hline & $\begin{array}{l}\text { Administrative } \\
\text { (strong-medium } \\
\text {-weak) }\end{array}$ & $\begin{array}{c}\text { Adaptive } \\
\text { (strong-medium } \\
\text {-weak) }\end{array}$ & $\begin{array}{c}\text { Enabling } \\
\text { (active-passive) }\end{array}$ & $\begin{array}{c}\text { Effectiveness } \\
([+] \text { effective } \\
\text {-ineffective }[-])\end{array}$ \\
\hline \multicolumn{5}{|c|}{ Replication } \\
\hline Company III & Strong & Weak & Passive - Active & $\begin{array}{c}+ \\
\text { (reduction } \\
\text { of complexity } \\
\text { - convergence) }\end{array}$ \\
\hline Company II & Strong & Strong - Medium & Active & + \\
\hline Company V & Strong & Weak & Passive & - \\
\hline \multicolumn{5}{|c|}{ Innovation } \\
\hline Company I & Strong & Strong & Active & + \\
\hline Company IV & Strong & Strong & Passive & - \\
\hline
\end{tabular}

The cases in the research sample made it possible to notice various influences of the enabling function. To be more precise, depending on whether the cases implemented replication or innovation of their experiences, the actions appropriate for the administrative or adaptive types were undertaken in a different order. Replication resulted in the fact that the ground for undertaking the action was first looked for in the scope appropriate for the administrative leadership, whereas obstacles which would appear served as a call for action (for enabling leadership) so that the existing "shortages" could be made up for in a creative manner (adaptive leadership). The sequence, therefore, ran from the legitimised system to the shadow. Enabling leadership was distinctly dominant in case of innovation. As a result, it was the dynamics of the shadow that guided the system towards creative solutions on every ground (also in the sphere of administrative leadership). The observation may be generally summarised in the following way: The assumptions resulting from experience are first responsible for the selection of actions appropriate for either administrative or adaptive leadership. Therefore, experience shapes a cognitive filter which is close either to the categorisation model (framework precedes data) or sense-making framework (data precedes framework).

Companies IV and V are the cases considered ineffective. Both companies withdrew from the market, although they did not resign from their development plans.
Company IV (innovation) manifested its eagerness to adapt; however, it seems that there was a lack of sufficient support of actions within the scope of enabling leadership. One strong leader played a significant role in this company (its founder, president of the management board and main owner). Company V (replication) was not willing to adapt; enabling leadership was not apparent. What connects both companies is the fact that (contrary to the efficient companies: Company I - innovation and Company - replication, respectively) they did not develop sufficiently strong actions within the scope of all three leadership types.

\section{Summary}

The application of the complexity theory in organisation and management studies leads to a reflection upon deeply rooted assumptions which are often accepted by the researches in a silent way. Although the very complexity theory may lead its research assumptions more towards its mathematic aspect (simple rules) or in a way that takes into consideration unique values of social systems (social complexity), in each case it points out interesting paths of further research. The same concerns the issue of leadership. The content of the paper was devoted to a detailed exploration of the nature of leadership behaviours and its impact on organisational performance in MNEs in turbulent environments. Such perception of the research ground was the 
result of the fact that the majority of the most prominent literature in the field was developed on the basis of results of studies conducted within large enterprises. EMs, due to their characteristic features, additionally create a very attractive context of research.

The cases of the investigated enterprises exemplify two ways how the organisation may handle environment complexity. The first one consists in the reduction of complexity (convergent type), which corresponds to MNE vision reinforced in the traditional literature in the field of international business. The other one consists in the complexity absorption (divergent type), whereas the enterprises which successfully apply such approach are young, small enterprises, also from EMs, and therefore lacking traditional bases for an advantage on a global scale. The foundations of their success in development of actions in the conditions of emerging envi- ronment helped to emphasise the perception of leadership from the perspective of the complexity theory. The applied theoretical framework (CLT, the concept of pillars of the environment, engagement with institution of foreign market) made it possible to put the obtained results of the study in a clear order (agent-system-pattern).

The actions appropriate for the administrative, adaptive and enabling types of leadership in the investigated enterprises could be assigned to domains set by the regulative, normative and cognitive pillars of the institution environment. Interestingly enough, relationships between certain leadership types and institutions were more intense than others (Figure 1). Therefore, it may be stated that particular institutions attract actions suitable for particular leadership types. If that is the case, the domination of a given leadership function may suggest development tendencies of the organisation in the environment.

Figure 1. Relationship of leadership function, pillars of the environment, and the way of engagement with institutions of a foreign market

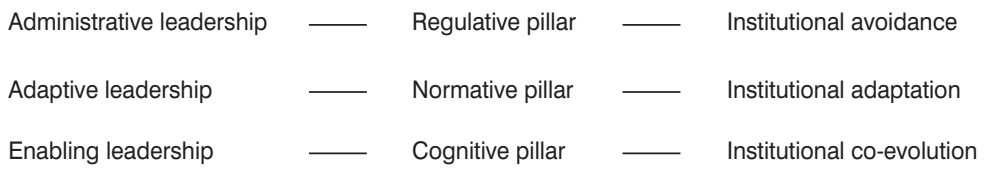

What must be emphasised is that the relationships presented in Figure 1 are simplified since the figure does not take into consideration the feedback. ${ }^{3}$ In this context, the implementation of tasks of an legitimated (official) system, i.e. the achievement of basic, current goals of the system in a possibly most efficient way, is based on a negative feedback thanks to which the status quo is obtained. Within its scope, the nearest future of the system might be foreseen since it is characterised by the regularity of behaviours, order and balance. ${ }^{4}$ The shadow of the system is characterised by greater and different dynamics which, to a large extent, depends on people's personality, their expectations and emotional states (Rokita and Dziubińska, 2016). From this point of view, since administrative leadership is connected with the authorised system of the organisation, it may lead to the formation of more predictable trajectories of development than in case of adaptive and enabling leadership functions. But on the other hand, unforeseen changes may appear to be very dramatic.

The advantage of the conducted studies is their application in the empirical context of the theoretical framework, the results of which seem to partially confirm and partially develop CLT. However, the constraints resulting from the selected qualitative approach, including, above all, the lack of possibility to extend the obtained results to other cases than the ones in the research samples, should be emphasised. The use of existing data in the research should also be regarded as a constraint since, to some extent, they may not be perfectly adjusted to the research objectives. The results presented serve as a ground for further research. Ways of initiating the exchange of knowledge that could set in motion a potentially beneficial positive feedback, setting barriers within the framework of which the 
systems could self-regulate, determining initial conditions and monitoring emerging results could all serve as interesting directions of further studies.

\section{Endnotes}

1 Institutional voids of the market occur when an economically justified transaction (beneficial for both the seller and the buyer) cannot be finalised due to its indirect cost which is higher than net profits (Williamson, 1975; Williamson, 1998).

2 The article was prepared for the 3rd International Conference Entrepreneurship for the XXI Century. Images and Perspectives that took place on the $24^{\text {th }}$ and $25^{\text {th }}$ of November 2016 at the Faculty of Management, University of Warsaw.

3 Feedback is a circular proximate cause of connected elements where each element affects another one until the last one answers the first one, i.e. until the loop is closed (Capra, 1997). Feedback is a complex concept even when considered with reference to non-living systems. Negative feedback may balance the results of deviation which have the tendency to grow. Positive feedback develops when the system can no longer delete the deviation. Then it can be multiplied and lead to the so called escape (a kind of disintegration often observed in the physical world).

4 The assumption about the functioning of the authorised system on the basis of the negative feedback should be understood in relation to the assumed goals of the organisation. Again, it is a simplification which is to make the content presented clearer.

\section{References}

Allen, P. (1998a). Evolving in social science. In G. Altman and W.A. Koch (eds.), Systems: New paradigms for the human science. New York: Walter de Gruyter.

Allen, P. (1998b). Modelling complex economic evolution. In: F. Schwietzer and G. Silverberg (eds.), Selbstorganisation. Berlin, Duncker, Humblor.

Allen, P., Strathern, M., \& Baldwin J. (2006). Evolution drive: New understanding of change in socio-economic systems. Emergence: Complexity and Organization, 8(2), 229-238.

Allen, T.F.H., Allen, P.C., Malek, A., Flynn, J. and Flynn, M. (2009). Confronting economic profit with hierarchy theory: The concept of gain in ecology. Systems Research and Behavioral Science, 26(5), 583-599. DOI: 10.1002/sres.998

Allen, T.F.H., Tainter, J.A., Flynn, J., Steller, R., Blenner, E., Pease, M. and Nielsen, K. (2010). Inte- grating economic gain in biosocial systems. Systems Research and Behavioral Science, 27(5), 537-552. DOI: 10.1002/sres.1060

Allen, T.F.H., Tainter, J.A. and Hoekstra, T.W. (1999). Supply-side sustainability. Systems Research and Behavioral Science, 16(5), 403-427. DOI: 10.7312/alle10586

Anderson, P.W. (1999). Complexity theory and organization science. Organization Science, 10(3), 216-232.

Barabba, V., Pourdehnad, J. and Ackoff, R.L. (2002). On misdirecting management. Strategy \& Leadership, 30(5), 5-9. DOI: 10.1108/10878570210442498

Berger, P. and Luckmann, T. (1967). The social construction of reality: A treatise on the sociology of knowledge. London: Allen Lane.

Boisot, M. and Child, J. (1999). Organizations as adaptive systems in complex environments: The case of China. Organization Science, 10(3), 237-252. DOI: 10.1287/orsc.10.3.237

Brown, S.L. and Eisenhardt, K.M. (1997). The art of continuous change: Linking complexity theory and time-paced evolution in relentlessly shifting organizations. Administrative Science Quarterly, 42(1), 1-34. DOI: 10.2307/2393807

Cantwell, J.A., Dunning, J.H. and Lundan, S.M. (2010). An evolutionary approach to under-standing international business activity: The co-evolution of MNEs and the institutional environment. Journal of International Business Studies, 41(4), 567-586. DOI: 10.1057/jihs.2009.95

Capra, F. (1996). The web of life: A new scientific understanding of living systems. New York: Doubleday.

Casti, J.L. (1994). Complexification. London: Abacus.

Chislip, D.D. (2002). The collaborative leadership fieldbook: A guide for citizens and civic leaders. San Francisco: Jossey-Bass.

Choo, Ch.W. and Bontis, N. (eds.). (2002). The strategic management of intellectual capital and organizational knowledge. New York: Oxford University Press.

Corallo, A., Passiante, G. and Prencipe, A. (eds.). (2007). The digital business ecosystem. London: Edward Elgar Publishing.

Coupey, E. (2004). Digital business: Concepts and strategy. Upper Saddle River: Pearson/Prentice Hall.

Crosby, B.C. and Bryson, J.M. (2010). Integrative leadership and the creation and maintenance of cross-sector collaborations. Leadership Quarterly, 21(2), 211-230. DOI: 10.1016/j.leaqua.2010.01.003

Curtin, J.L. (2004). Emergent leadership: Case study of a jury foreperson. Leadership Review, 4, $75-88$. 
DiMaggio, P.J. and Powell, W.W. (1983). The iron cage revisited: Institutional isomorphism and collective rationality in organizational fields. American Sociological Review, 48(2), 147-160. DOI: $10.2307 / 2095101$

DiMaggio, P. (1988). Interest and agency in institutional theory. In L.G. Zucker (ed.), Institutional patterns and organizations: Culture and environment (pp. 3-21). Cambridge: Ballinger.

Dooley, K.J. and Van de Ven, A.H. (1999). Explaining complex organizational dynamics. Organization Science, 10(3), 358-372. DOI: 10.1287/orsc.10.3.373

Dziubińska, A. (2015). Konceptualna charakterystyka przedsiębiorstwa międzynarodowego - przedsiębiorstwo tradycyjne. Studia Ekonomiczne. Zeszyty Naukowe Uniwersytetu Ekonomicznego w Katowicach, 222, 34-52.

Dziubińska, A. (2017a). Strategie przedsiębiorstw międzynarodowych $\mathrm{z}$ teorią złożoności $\mathrm{w}$ tle. In K. Jędralska and W. Dyduch (eds.), Nauki o zarzadzaniu. Dokonania, trendy, wyzwania (pp. 215-235). Katowice: Wydawnictwo Uniwersytetu Ekonomicznego w Katowicach.

Dziubińska, A. (2017b). Innowacja instytucjonalna w warunkach transformacji otoczenia. Studia i Materiaty, 2(1), 48-59.

Eisenhardt, K.M. and Brown, L.S. (1999). Patching. Restitching business portfolios in dynamic markets. Harvard Business Review, 77(3), 72-82.

Eisenhardt, K.M. and Piezunka, H. (2011). Complexity theory and corporate strategy. In P. Allen, S. Maguire and B. McKelvey (eds.), The Sage handbook of complexity and management (pp. 506-523). London: Sage Publications.

Goldfinch, S.F. and Hart, P. (2003). Leadership and institutional reform: Engineering macroeconomic policy change in Australia. Governance, 16(2), 235-270. DOI: http://dx.doi.org/10.1111/14680491.00215

Grant, R.M. (2000). Shifts in the world economy: The drivers of knowledge management. In C. Despres and D. Chauvel (eds.), Knowledge horizons: The present and the promise of knowledge management (pp. 27-54). Boston: Butterworth Heinemann.

Grant, R.M. (2002). The knowledge-based view of the firm. In C.W. Choo and N. Bontis (eds.), The strategic management of intellectual capital and organizational knowledge. Milton Keynes: Open University Press.

Hargrave, T.J. and Van De Ven A.H. (2006) A collective action model of institutional innovation. Academy of Management Review, 31(4), 864-888. DOI: http://dx.doi.org/10.5465/ AMR.2006.22527458

Hazy, J.K. (2006). Measuring leadership effectiveness in complex socio-technical systems. Emergence:
Complexity and Organization, 8(3), 58-77. DOI 10.emerg/10.17357.35c842ca4c07405f1dd3545d33 21f38f

Herdon, M., Várallyai, L. and Péntek, Á. (2012). Digital business ecosystem prototyping for SMEs. Journal of Systems and Information Technology, 14(4), 286-301. DOI: https://doi. org/10.1108/13287261211279026

Holland, J. (1998). Emergence from chaos to order. New York: Oxford University Press.

Hymer, S. (1976). The international operations of national firms: A study of direct foreign investment. Cambridge: MIT Press.

Juarrero, A. (1999). Dynamics in action: Intentional behavior as complex systems. Boston: MIT Press.

Karakas, F. (2009). New paradigms in organization development: Positivity, spirituality and complexity. Organization Development Journal, 27(1), 11-26. Kauffman, S.A. (1995). At home in the universe New York: Oxford University Press.

Kaufmann, S.A. (1993). Origins of order: Self-organization and selection in evolution. Oxford: Oxford University Press.

Khanna, T. and Palepu, K.G. (2010). Winning in emerging markets: A road map for strategy and execution. Boston: Harvard Business Press.

Kingdon, J.W. (1984). Agendas, alternatives and public policies. New York: Harper Collins.

Kostova, T. and Zaheer, S. (1999). Organizationa legitimacy under conditions of complexity: The case of the multinational enterprise. Academy of Management Review, 24(1), 64-81. DOI: 10.2307/259037 Langton, C.G. (1996). Artificial life. In S.A. Boden (ed.), The philosophy of artificial life. Oxford: Oxford University Press.

Laudon, K.C. and Laudon, J.P. (2013). Management information systems: Managing the digital firm (13th ed.). Upper Saddle River: Pearson/Prentice Hall.

Levy, D. (1994). Chaos theory and strategy: theory, application, and managerial implications. Strategic Management Journal, 15, 167-178.

Lichtenstein, B.B., Uhl-Bien, M., Marion, R., Seers, A., Orton, J.D. and Schreiber, C. (2006) Complexity leadership theory: An interactive perspective on leading in complex adaptive systems. Emergence: Complexity and Organization, 8(4), 2-12.

Lipman-Blumen, J. (1996). Connective leadership Managing in a changing world. New York: Oxford University Press.

Luke, J.S. (1998). Catalytic leadership: Strategies for an interconnected world. San Francisco: Jossey-Bass Maccoby.

Maguire, S., McKelvey, B., Mirabeau, L. and Öztas, N. (2006). Organizational complexity science. In: S. Clegg, C. Hardy, W. Nord and T. Law- 
rence (eds.), Handbook of organizational studies (2nd ed.) (pp. 165-214). Thousand Oaks: Sage.

Marion, R. (1999). The edge of organization: Chaos and complexity theories of formal social systems. Thousand Oaks: Sage.

Marion, R. and Uhl-Bien, M. (2003). Complexity v. transformation: The new leadership revisited (working paper). Clemson University, Clemson, SC.

McKelvey, B. (2001). Energizing order-creating networks of distributed intelligence. International Journal of Innovation Management, 5, 181-212. DOI: https://doi.org/10.1142/S1363919601000348

Mcquivey, J. (2013). Digital disruption: Unleashing the next wave of innovation. Las Vegas: Amazon Publishing.

Meyer, J.W. and Rowan, B. (1977). Institutionalized organizations: Formal structure as myth and ceremony. American Journal of Sociology, 83, 340-363. DOI: $10.1086 / 226550$

Meyer, J.W. and Scott, W.R. (eds.) (1983). Organizational environments: Ritual and rationality. Beverly Hills: Sage Publications.

Nooteboom, S.G. and Termeer, C. (2013). Strategies of complexity leadership in governance systems. International Review of Public Administration, 18(1), 25-40. DOI: 10.1080/12294659.2013.10805238

North, D.C. (1990). Institutions, institutional change and economic performance. Cambridge: Harvard University Press. DOI: 10.1017/ CBO9780511808678

North, D.C. (2005). Understanding the process of economic change. Princeton: Princeton University Press.

Odum, H.T. and Obadum, E.C. (2006). The prosperous way down. Energy, 31(1), 21-32.

Oliver, C. (1991). Strategic responses to institutional processes. Academy of Management Review, 16(1), 145-179. DOI: 10.5465/AMR.1991.4279002

Osborn, R.N., Hunt, J.G. and Jauch, L.R. (2002) Towards a contextual theory of leadership. The Leadership Quarterly, 13, 797-837.

Peng, M.W. (2003). Institutional transitions and strategic choices. Academy of Management Review, 28(2), 275-296.

Peng, M.W. and Heath, P. (1996). The growth of the firm in planned economies in transition: Institutions, organizations, and strategic choice. Academy of Management Review, 21(2), 492-528.

Powell, W. (1990). Neither market nor hierarchy: Network forms of organization. Research in Organizational Behavior, 12, 295-336.

Raffaelli, R. and Glynn, M.A. (2015). Institutional innovation: Novel, useful, and legitimate. In Ch.E. Shalley, M.A. Hitt and J. Zhou (eds.), The Oxford handbook of creativity, innovation, and entre- preneurship. Oxford: Oxford University Press. DOI 10.1093/oxfordhb/9780199927678.001.0001

Rokita, J. (in print). Zarzadzanie strategiczne zasobami ludzkimi z perspektywy nauki o ztożoności.

Rokita, J. and Dziubińska, A. (2016). Systemy ztożone w zarzadzaniu. Katowice: Wydawnictwo Uniwersytetu Ekonomicznego w Katowicach.

Schmidt, E. and Cohen, J. (2013). The new digital age: Transforming nations, businesses, and our lives. New York: Vintage Books.

Scott, W.R. (2004). Reflections on a half-century of organizational sociology. Annual Review of Socio$\log y, 30,1-21$

Scott, W.R. (2001). Institutions and organizations. Thousands Oak: Sage.

Snowden, D. and Stanbridge, P. (2004). The landscape of management: Creating the context for understanding social complexity. Emergence: $\mathrm{Com}$ plexity and Organization, 6(1-2) (Special Double Issue), 140-148.

Stacey, R. (1996). Complexity and creativity in organizations. San Francisco: Berrett-Koehler Publishers.

Stacey, R.D. (2011). Strategic management and organisational dynamics. The challenge of complex ity to ways of thinking about organisations. Harlow: Pearson.

Strader, T.J. (2010). Digital product management, technology and practice: Interdisciplinary perspectives. Hershey: IGI Global. DOI: 10.4018/978-161692-877-3

Surie, G. and Hazy, J. (2006). Generative leadership: Nurturing innovation in complex systems. Emergence: Complexity and Organization, 8(4), 13-26.

Tapscott, D. (2015). The digital economy: Rethinking promise and peril in the age of networked intelligence (20th anniversary ed.). New York: McGraw-Hill Education.

Thietart, R.A. and Forgues, B. (1995). Chaos theory and organization. Organization Science, 6, 19-31. DOI: 10.1287/orsc.6.1.19

Reynolds, C.W. (1987). Flocks, herds and schools: A distributed behavioral model. Proceeding $S I G$ GRAPH '87. Proceedings of the 14th annual conference on computer graphics and interactive techniques, 25-34.

Ray, T.S. (1991). An approach to the synthesis of life. In: C. Langton, C. Taylor, J.D. Farmer and S. Rasmussen (eds.), Artificial life II. Santa $F e$ Institute Studies in the Sciences of Complexity, XI, (pp. 371-408). Redwood City: Addison-Wesley.

Tsoukas, H. and Hatch, M.J. (2001). Complex thinking, complex practice: The case for a narrative approach to organizational complexity. Human Relations, 54(8), 979-1013. 
Uhl-Bien, M., Ross, M. and McKelvey, B. (2007). Complexity leadership theory: Shifting leadership from the industrial age to the knowledge era. The Leadership Quarterly, 18(4), 298-318. DOI: 10.1016/j.leaqua.2007.04.002

Uhl-Bien, M. and Ross, M. (2009). Complexity leadership in bureaucratic forms of organizing: A meso model. The Leadership Quarterly, 20(4), 631-650. DOI: 10.1016/j.leaqua.2009.04.007

Williamson, O.E. (1975). Markets and hierarchies: Analysis and antitrust implications. New York: Free Press.

Williamson, O.E. (1991). Comparative economic organization: The analysis of discrete structural alternatives. Administrative Science Quarterly, 36, 269-296. DOI: $10.2307 / 2393356$

Williamson, O.E. (1998). Ekonomiczne instytucje kapitalizmu. Warszawa: Wydawnictwo Naukowe PWN.

Zhichang, Z. (2007). Complexity science, system thinking and pragmatic sensibility. System Research and Behavioral Science, 24(4), 445-464. DOI: http:// dx.doi.org/10.1002/sres.846

Zimmerman, M. and Zeitz, G. (2002). Beyond survival: Achieving new venture growth by building legitimacy. Academy of Management Review, 27(3), 414-431. DOI: 10.5465/AMR.2002.7389921 